\title{
sciendo MITIGATING UNCERTAINTIES IN DECISION MAKING IN EARLY PHASES OF RFID IMPLEMENTATION
}

doi:10.2478/mape-2018-0055

Date of submission of the article to the Editor: 05/2018

Date of acceptance of the article by the Editor: 07/2018

MAPE 2018, volume 1, issue 1, pp. 433-441

\author{
Dr Bartlomiej Gładysz \\ Warsaw University of Technology, Poland
}

\begin{abstract}
Radio Frequency Identification (RFID) is still a relatively new technology for many manufacturing and logistics companies. These companies experience uncertainties about RFID implementation, so they take steps to mitigate them. This article presents multiple case studies to design a conceptual framework to mitigate such barriers. The goal of this research was to test propositions that companies: often are not convinced about the maturity and performance of RFID technology; perform typical actions to test uncertainties; and need proof of the benefits of RFID technology before implementation. It was demonstrated that companies conduct proof of RFID technology activities (demonstrations and reference visits) to test RFID performance. These are required to test the technology in operation. Conclusions of this research may serve RFID systems providers and end users of technology by facilitating a better understanding of decision making processes during early phases of RFID implementation.
\end{abstract}

Keywords: Radio Frequency Identification (RFID); multiple case study; project scoping and feasibility; mitigating uncertainties

\section{INTRODUCTION}

Supply chains consist of flows of goods, data, ownership and/or responsibility, and money. Problems in supply chain management are related to improper flow of data and improper communication processes in general. Flows of goods and data should be concurrent, accurate, and trans-parent to enable decision-making based on real and accurate data - the key for successful supply chain management.

Automated identification (auto-identification) technologies eliminate communication distortions and delays or errors in data flow. One such technology is Radio Frequency Identification (RFID), which is receiving increasing interest among manufacturing and logistics companies. RFID has two key benefits; it enables data flow at the moment the flow of goods takes place - thereby eliminating communication delays, while simultaneously eliminating errors due to improper identification. RFID has wide application, but it is still a relatively new technology for many companies. This is especially true considering the Polish market. As the technology is not well-known or commonly used, companies require careful tests before they make investment decisions (Gladysz, 2014). There has been limited discussion regarding the impact of adopting RFID and how those decisions are effected by other factors (Ramanathan et al., 2014). This study aims to highlight a conceptual framework of activities taken by manufacturing and logistics companies to mitigate uncertainties about RFID implementation.

For this study, each time radio frequencies (RF) are used to identify and/or locate a tagged object, they are classified as RFID technology. RFID technology is every technology based on radio frequencies (no matter the standards) that enable the process of identification and/or location.

There are many areas of RFID applications; warehouse inventory tracking and management, manufacturing logistics, control of material flows, management of picking, receiving and shipping, process monitoring, tracking of work in progress (WIP), quality control, tool 
management, external supply chain management, life cycle management and return logistics (Liukonnen, 2015). Detailed description of the physics involved and RFID applications has been subject of many publications (Dobkin, 2012; Finekenzeller, 2010).

However, application of RFID technologies has not always been effective, nor economically feasible (Bendavid et al., 2009). One such analytical process uses a modular approach to early decision making and strategic assessment, addressing: 1) evaluation of strategic potential of RFID-based improvement of supply chain; 2) selection of a process for RFIDbased improvement; 3) design of new and/or improved processes; and 4) evaluation of proposed RFID-based improvements (Gladysz, 2015).

RFID is an increasingly popular technology supporting supply chains and logistics (Elia and Gnoni, 2013). It is a dynamic, developing, and innovative technology, especially considering the economy of Poland (Gladysz, 2014; 2012).

RFID is a type of information and communication technology (ICT), and uses a similar implementation framework. Therefore, it is important to focus on hardware and software issues, and their integration with other ICT (e.g., enterprise re-sources planning), physical systems (e.g., dock doors), or cyber-physical systems.

Ngai et al. (2010) proposed a seven stage frame-work for RFID implementation processes: 1) project feasibility and scoping; 2) project team formation; 3) 'as-is' assessment; 4) process redesign - 'to-be' processes; 5) hardware adaption to the environment; 6) system implementation; and 7) continuous improvement. A very similar approach was proposed by Ting et al. (2013), including six stages: 1) project scoping; 2) analysis of the existing system; 3) system design; 4) prototype testing; 5) implementation; and 6) continuous improvement. These two frameworks are generic and applicable to any ICT implementation. In both processes, strategic assessments of RFID implementation in manufacturing companies are applicable (Gladysz, 2015). Key success factors for RFID implementation projects do not differ significantly from other projects and include: 1) vendor selection; 2) organizational motivation; 3) cost/benefits evaluation; 4) top management support; 5) user involvement; 6) extent of progress supervision; 7) staff competence and training; and 8) policy, structure and operation process compatibility (Ngai et al., 2012).

Numerous authors reported benefits of RFID applications in different sectors; production logistics (Zelbst et al., 2012), warehousing (Osyk et al., 2012), and external supply chains (Sarac et al., 2010). At the same time, authors identified difficulties with return on investment calculations and high costs. Based on a study of 10 companies, Mehrjerdi (2011) proposed detailed list of 79 types of possible benefits from RFID implementation. Such benefits may be summarized in two main categories; 1 ) increased efficiency and speed of processes, and 2) increased visibility and accuracy of processes. The benefits are substantial, especially when the flow of objects is massive and hard to manage, and/or goods are valuable, so it is necessary to identify the value of goods and de-lays or lack of information flow that lead to mis-takes and/or increased costs. Reyes et al. (2016) discussed determinants of RFID adoption stage discussing benefits (customer service, productivity, asset management and communication) and barriers (cost issues, lack of understanding, technical issues and privacy issues). They highlighted, that internal drivers, top management leadership, cost barrier and firm size are significant determinants of the stage of RFID adoption.

Although RFID is not a new technology and there are many examples of successful implementation, it is still not commonly adopted in many industries. According to Moore's (2014) model, RFID technology is currently crossing this chasm (Roberti, 2017). However, this effort has been expected for the past 10 years (Alien technology, 2017). In many industries, early adopters still face problems with assessing potential implementation barriers. It is unclear what actions are necessary and if they would be effective. The goal of this study is to analyse examples of early adopters and examine what actions do they perform in early phases of the decision making process. 


\section{METHODOLOGY}

The literature on RFID, its applications, benefits and implementation frameworks is very broad. It primarily addresses how to manage implementation projects (Ngai et al., 2010; 2012; Ting et al., 2013). Benefits and costs are widely discussed using simulation and case studies (Zelbst et al., 2012; Osyk et al., 2012; Sarac et al., 2010; Mehrjerdi, 2011). However, it is not clear what limits the implementation process in the context of manufacturing and logistics companies and why many projects are stopped during the early phases. An attempt to these problems is an aim of presented research. Research procedure is depicted on Fig. 1.

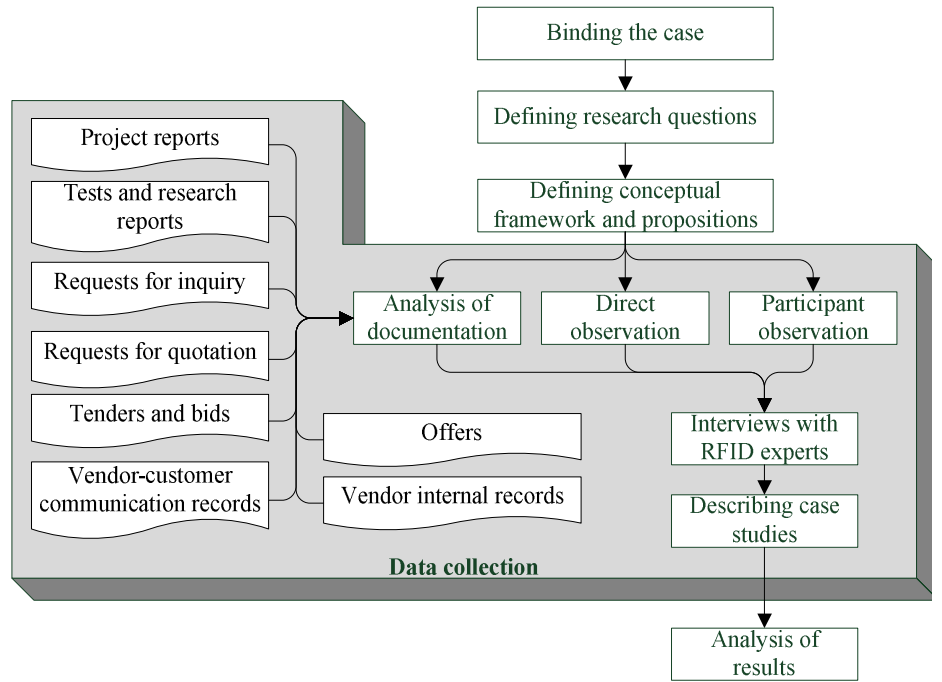

Fig. 1. Research procedure

This research focuses on three research questions:

- Q1. How do decision makers mitigate uncertainties about RFID immaturity (poor performance) in the context of selected manufacturing and logistics companies?

- Q2. Are there repetitive activities performed to mitigate uncertainties mentioned in Q1?

- Q3. Which activities were successful in terms of uncertainties mitigation mentioned in Q1? These general questions address the "how" and "why" of the implementation process. Because behaviours of organizations involved in the study could not be manipulated, contextual conditions are relevant and are therefore addressed. Accordingly, the case study format was selected as a relevant methodology to create robust and reliable results (Yin, 2003). Multiple case studies are included to understand the similarities and differences across the field. To avoid questions too broad in scope, or a topic that has too many objectives for one study, boundaries are placed for each presented case; time, place, definition, and context (see Table 1) (Baxter and Jack, 2008).

Table 1

Boundaries of case study

\begin{tabular}{|c|l|}
\hline Time & related to years 2011-2016 \\
\hline Place & limited to implementations in Poland \\
\hline \multirow{4}{*}{$\begin{array}{c}\text { Definition } \\
\text { and } \\
\text { context }\end{array}$} & \begin{tabular}{l} 
related to the RFID definition presented in the section "RFID technology" \\
\cline { 2 - 3 } \\
limited to: \\
- manufacturing and logistics (M\&L) companies of C (manufacturing) and H (transportation and \\
- medium and large companies \\
- cases that passed first sales stages (presentations etc.), cases when customer decided to \\
participate actively in further activities e.g. in terms of costs \\
- cases when vendor/integrator was included in project scoping and feasibility \\
- limited to cases when potential customers showed commitment to the project and RFID was "pulled" \\
by them, rather than "pushed" by vendor
\end{tabular} \\
\hline
\end{tabular}


Three experts implementing RFID in Poland since 2006, and having implemented a dozen RFID systems from 2011-2016, were interviewed. Three propositions were formulated based on their professional and scientific experience:

- P1. Manufacturing and Logistics companies often are not convinced about the maturity of technology and want to check it in terms of read accuracy, read range, and durability.

- P2. There are typical actions performed by Manufacturing and Logistics companies to test above uncertainties (see P1).

- P3. Decision makers from Manufacturing and Logistics companies require proof of RFID technology.

Cases were examined to find appearance of some specific activities performed during early decision making; demonstrations, tests, and reference site visits. The following definitions were adopted for those activities:

1. Demonstration: a relatively short presentation (preparation plus half day or less) of technology in action for decision makers. It illustrates the general ability of the technology to operate effectively within assumed demonstration conditions;

2. Tests: evaluations required and performed at the demand of the customers who want to actively participate and analyse results in order to make decisions;

a. Internal tests - tests performed by solution provider internally, without customer's involvement and interest in the process. These tests are common practice and necessary in any implementation, and are therefore out of the scope of this study;

b. Tests at customer site - a type of extension of a demonstration, which is necessary from customer's point of view to examine RFID effectiveness for somehow longer period (ca. 2 weeks). Period is longer than for a demonstration and conditions of activity are much less controlled. Customer examines technology in different and sometimes fuzzy scenarios (Grabia, 2015);

c. Laboratory tests - activity related to a very detailed analysis of technology performance is conducted to determine optimal RFID and its environment settings (chips, location, and orientation of tags, antennas, etc.) (Gladysz et al., 2017);

3. Reference site visit: an activity showing similar solutions to final users and decision makers. "Similar solution" is fuzzy term, but relates to a system operating in same branch, industry or process type, where the logic of improved process, tagged objects and reading points is understandable by decision makers and translatable to their own processes and environment. Ideally, it is a system that is applicable with some relatively minor adaptations. A conceptual framework (see Fig. 2) was con-structed to describe who will and will not be included in study and what relationships may be present, based on logic and experience of interviewed RFID experts. That framework was con-structed using the notation industrial dynamics (Forrester, 1961).

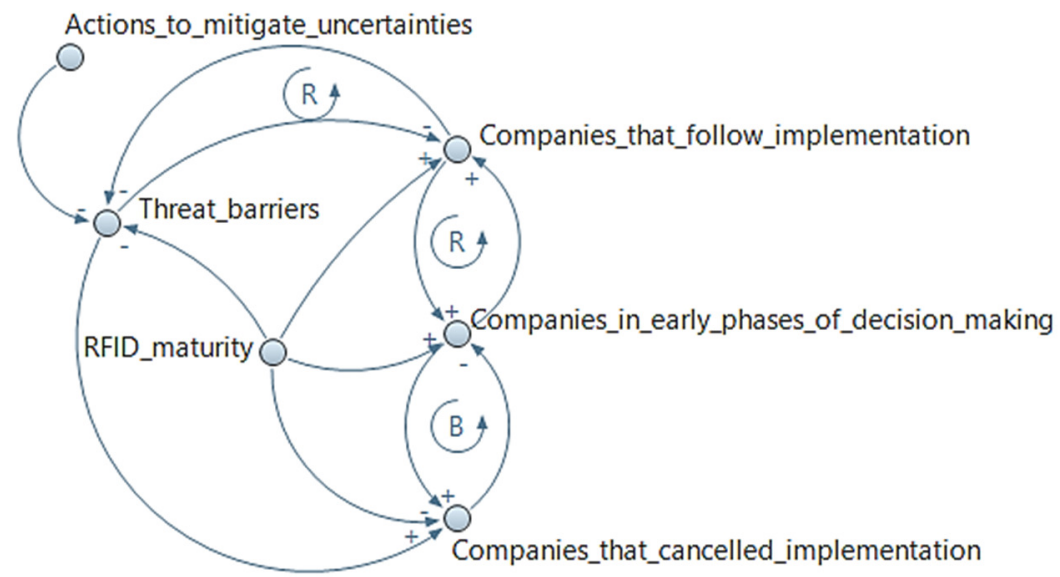

Fig. 2. Conceptual framework 
"Actions to mitigate uncertainties" refers to the set of above discussed activities; demonstrations, tests, and reference visits. It was assumed that an implementation process is slowed down and/or cancelled during early phases due to the lack of proofs regarding: 1) RFID technology maturity, and 2) its capability to operate under specific conditions of the company that makes decision. It is assumed that this uncertainty is over-come by the execution of the "Actions to mitigate uncertainties". Data sources include documentation and archival records, implementation project reports and records, test and research reports, vendor-customer communication records, requests for inquiry, request for quotation, offers, tenders and bids, and vendor internal records. Interviews were performed with two RFID experts from RFID systems vendor/integrators and decision makers at the side of RFID users. Direct and participant observations were also employed.

\section{RESULTS}

Thirteen cases were studied from 2011-2017. Description of their details is presented in Appendix A. Main characteristics of analysed case studies are collected in Table 2 and statistics in Table 3.

Table 2

Characteristics of case studies

\begin{tabular}{|c|c|c|c|c|c|}
\hline $\begin{array}{c}\text { Cas } \\
\mathrm{e}\end{array}$ & Demonstration & $\begin{array}{c}\text { Tests at } \\
\text { customer's site }\end{array}$ & $\begin{array}{l}\text { Laboratory tests on } \\
\text { customer's demand }\end{array}$ & $\begin{array}{l}\text { Reference } \\
\text { site visit }\end{array}$ & Status \\
\hline A & $+/-$ (hardware) & - & - & + & finished \\
\hline $\mathrm{B}$ & + (hardware) & + & - & - & paused for $0.5 \mathrm{yr}$ \\
\hline C & + (hardware) & $+/-$ & - & - & cancelled \\
\hline $\mathrm{D}$ & + (software) & - & - & - & finished \\
\hline$E$ & + (hardware) & + & - & - & cancelled \\
\hline $\mathrm{F}$ & + (hardware) & + & + & - & paused for $1 \mathrm{yr}$ \\
\hline$G$ & + (hardware) & + & $+/-$ & - & in progress \\
\hline $\mathrm{H}$ & + (software) & - & - & $+/-$ & finished \\
\hline $\mathrm{I}$ & + (hardware) & + & - & - & finished \\
\hline $\mathrm{J}$ & + (software) & - & - & - & finished \\
\hline $\mathrm{K}$ & $\begin{array}{l}\mathrm{K} 1 .+ \text { (hardware) } \\
\mathrm{K} 2 .+ \text { (hardware) }\end{array}$ & + & - & - & paused \\
\hline $\mathrm{L}$ & - & - & - & + & finished \\
\hline $\mathrm{M}$ & + (hardware) & + & - & - & cancelled \\
\hline
\end{tabular}

Table 3

Statistics of case studies

\begin{tabular}{|l|l|c|}
\hline \multicolumn{1}{|c|}{ Characteristic } & \% of occurrence \\
\hline Application type & Closed loop & $85 \%$ \\
\cline { 2 - 3 } & Open loop & $31 \%$ \\
\hline \multirow{3}{*}{ Integration with other } & Yes & $15 \%$ \\
\cline { 2 - 3 } & Partial & $8 \%$ \\
\cline { 2 - 3 } & No, but ready & $38 \%$ \\
\cline { 2 - 3 } & No & $38 \%$ \\
\hline \multirow{4}{*}{ Standions present } & UHF & $92 \%$ \\
\cline { 2 - 3 } & UWB & $15 \%$ \\
\cline { 2 - 3 } & Demonstration & $92 \%$ \\
\cline { 2 - 3 } & Tests at customer's site & $61 \%$ \\
\cline { 2 - 3 } & Laboratory tests on customer's demand & $15 \%$ \\
\cline { 2 - 3 } & Reference site visit & $23 \%$ \\
\cline { 2 - 3 } & One or more of above & $100 \%$ \\
\cline { 2 - 3 } & Two or more of above & $77 \%$ \\
\cline { 2 - 3 } & Three or more of above & $15 \%$ \\
\cline { 2 - 3 } & Four of above & $0 \%$ \\
\hline
\end{tabular}




\section{DISCUSSION}

It was difficult to identify typical reasons for cancellations or pauses of projects because each case presented unique conditions. But high investment costs and inappropriate definition of assumptions did impact implementation, necessitating re-scoping of the project.

A few statistics from the cases analysed are of interest (see Table 2). 85 percent of cases were closed-loop applications of RFID, while only 31 percent were open loop. Case F had both applications.

There was only one case when a company was uncertain about RFID effectiveness (Case L). In this case, the implemented solution was highly similar to another implemented by a customer previously discussed. In this case, a reference site visit was the only action taken, but necessary to promote project to all phases of implementation. All other cases included actions related to testing RFID effectiveness, read accuracy, etc. RFID systems are not offthe-shelf solutions and always require customization for specific to customer needs. Considering all cases, at least one action (demonstration, tests at customer's site, laboratory tests, or a reference site visit) was always pre-sent (see Table 3). The proposition was confirmed.

Cases were examined in terms of the use of the following actions: demonstration, tests at customer's site, laboratory tests on demand of customer, and reference site visits. Analysis confirmed that there were some activities usually undertaken to test uncertainties about RFID effectiveness. Demonstrations and tests at customer sites seemed typical, occurring 12 and 9 times respectively, in 13 total cases (see Table 3). Demonstration was not present at all in case $L$. Case $L$ included a reference visit and integration with the supply chain in which the customer was already operating an RFID solution. In other cases, an RFID system was demonstrated. If demonstration of all the components was not possible or too costly, then demonstration of an information system (implemented together with RFID) was performed carefully (cases $\mathrm{D}, \mathrm{H}$, and $\mathrm{J}$ ). However, the proposition cannot be fully confirmed, as there was no single action present in all cases. The only generalization drawn from the analysed cases is that all contained some evaluation activities, but there no single action that can be found in all cases.

All the cases included at least one of following phases: demonstration, tests at customer site, laboratory tests on customer's demand, or a reference visit. Four cases (A, D, J, and L) included only one of the listed phases, but 10 cases included two or three phases (see Table 3). There was no case including all the mentioned phases. This is likely due to the fact that reference visits were rarely possible (only three cases) and laboratory tests were rarely expected and only if a reference visit was not possible. Although reference visits were rarely possible, they seemed to be very effective to overcome uncertainties. Two cases ( $A$, and $L)$ of successful implementation included only a reference visit. There were cases without considered actions. The proposition was con-firmed, as companies analysed needed proof of RFID technology.

\section{CONCLUSION}

This research gave promising results in terms of positive verification of the propositions. However, findings are limited due to very general sample selection. This research should proceed further, with separate focus on manufacturing and logistics companies. Due to the nature of the case study format, findings are limited to the conceptual framework. Case studies were limited to Polish companies, as it was assumed that Polish companies are unique due to their operating and economic environment. However, research should be extended to examine what similarities and/or differences exist, dependent on the economy. Nevertheless, research limited to large sized Polish manufacturing and logistics companies represents a good starting point for further study. It may provide generic guidelines for any RFID adopter whose company has similarities to those examined in this study. It may also serve as a guideline for RFID solution providers and system integrators on how to operate within similar markets. 
As a result of this study, two of the three defined propositions were confirmed. One proposition could not be confirmed. It was demonstrated that a significant barrier to companies considering implementation of RFID is the lack of effectiveness in terms of read accuracy, reading distances, etc. This uncertainty results from lack of data due to low levels of adoption in Polish companies, leaving implementation to innovators and early adopters. It was demonstrated that Polish companies usually perform some typical actions to test uncertainties, including; demonstration, tests at company sites, and reference visits, to see the technology in operation. Users (decision makers and/or their advisors) want to see and actively participate in proof of RFID technology (demonstrations or reference visit) to test its performance and potential. In this regard, RFID systems do not differ significantly from other products (systems), especially those that are in the early phases of their lifecycles. Another direction of future re-search is an extension of the conceptual causal loop and design of the stock-flow model, as presented above. The purpose is to simulate the process of mitigating uncertainties in early phases of decision making.

This research needs further advancement to test differences between manufacturing and logistics companies, and assess customer points of view. To this end, interviews and questionnaires with decision makers are recommended.

\section{ACKNOWLEDGMENT}

The author is grateful to Mr Marek Czarzynski and Mr Cezary Lysiak of HADATAP Ltd for the cooperation during the period of this research. The author thanks prof. Krzysztof Santarek of the Warsaw University of Technology for his remarks and guidelines on preparation of the research.

\section{REFERENCES}

Alien Technology (2015). RFID Goes Mainstream. [online] Available at: http://www.alientechnology.com/wp-content/uploads/Whitepaper-RFID-Goes-Mainstream-AnAlien-Technology-Viewpoint.pdf (Accessed 10 Aug. 2017).

Baxter, P. and Jack, S. (2008). Qualitative Case Study Methodology: Study Design and Implementation for Novice Researchers. The Qualitative Report, 13(4), pp. 544-559.

Bendavid, Y., Lefebvre, E., Lefebvre, L. A. and Fosso Wamba S. (2009). Key performance indicators for the evaluation of RFID-enabled B-to-B e-commerce ap-plications: The Case of a Five-Layer Supply Chain. Inf. Syst. and E-Bus. Manag., 7(1), pp. 1-20.

Dobkin, D.M., The RF in RFID: UHF RFID in Practice. 2nd ed. Oxford: Newnes.

Elia, V. and Gnoni M. (2013) Pervasiveness of RFID technology: A survey based on case studies analysis. Int. J. of RF Technol., 5(1-2), pp. 41-51.

Eurostat (2008). NACE Rev. 2 - Statistical classification of economic activities in the European Community. Luxembourg: European Communities.

Finkenzeller, K. (2010). RFID Handbook, New York: John Wiley \& Sons.

Forrester, J. (1961). Industrial Dynamics. Cambridge: MIT Press.

Gladysz, B. (2012). RFID technology markets in Poland (in Polish: Rynki RFID w Polsce). Ekonomika i Organizacja Przedsiębiorstwa, 7, pp. 31-42.

Gladysz, B. (2014). RFID technology markets in Poland (2014) (in Polish: Rynki RFID w Polsce (2014)). Ekonomika i Organizacja Przedsiębiorstwa, 5, pp. 47-55.

Gladysz, B. (2015). An assessment of RFID applications in manufacturing companies. Manag. and Prod. Eng. Review, 6(4), pp. 33-42.

Gladysz, B., Lysiak, C., Grabia, M. and Markowski, T. (2017). Assessment of RFID technology performance in fertilizers environment. In: IEEE RFID-TA 2017. Warsaw (Poland): IEEE, pp. 146151.

Grabia, M. (2015). Assessment of effectiveness of the use of RFID technology in selected processes at DIY retail store. In: IEEE RFID-TA 2015. Tokyo: IEEE, pp. 134-140.

Liukkonen, M. (2015). RFID technology in manufacturing and supply chain, in Int. J. of Computer Integrated Manufacturing, 28(2), pp. 861-880.

Mehrjerdi, Y. (2011). RFID and its benefits: a multiple case analysis. Assembly Automation, 31(3), pp. 251-262.

Moore, G. (2014). Crossing the Chasm. 3rd ed. New York (NY): Harper Business.

Ngai, E.W.T., Chau, D.C.K., Poon, J.K.L., Chan, A.Y.M., Chan, B.C.M. and Wu, W.W.S. (2012). Implementing an RFID-based manufacturing process management system: Lessons learned and success factors. J. of Eng. and Technol. Manag., 29(1), pp. 112-130. 
Ngai, E.W.T., To, C.K.M., Moon, K.K.L., Chan, L.K., Yeung, P.K.W. and Lee, M.C.M. (2010). RFID systems implementation: a comprehensive framework and a case study. Int. J. of Prod. Res., 48(9), pp. 2583-2612.

Osyk, B.A., Vijayaraman, B.S., Srinivasan, M. and Dey, A. (2012). RFID adoption and implementation in warehousing. Manag. Res. Rev., 35(10), pp. 904-926.

Ramanathan, R., Ramanathan, U. and Ko L. (2014). Adoption of RFID technologies in UK logistics: Moderating roles of size, barcode experience and government support, Expert Syst. with Applicat., 41(1), pp. 230-236.

Reyes, P., Li, S. and Visich, J. (2016). Determinants of RFID adoption stage and perceived benefits. Eur. J. of Oper. Res., 254(3), pp. 801-812.

Roberti, M. (2017). RFID Starts to Go Mainstream. [online] in RFID J. Available at: http://www.rfidjournal.com/articles/view?16141 (Accessed 11 Aug. 2017).

Sarac, A., Absi, N. and Dauzére-Pérés, S. (2010). A literature review on the impact of RFID technologies on sup-ply chain management. Int. J. of Prod. Econ., 128(1), pp. 77-95.

Ting, S., Tsang, A. and Tse Y. (2013). A Framework for the Implementation of RFID Systems. Int. J. of Eng. Bus. Manag., 5(9), pp. 1-16.

Yin, R. (2003). Case study research: Design and methods, Thousand Oaks: Sage.

Zelbst, P.J., Green, K.W., Sower, V.E. and Reyes P.M. (2012). Impact of RFID on manufacturing effectiveness and efficiency. Int. J. of Oper. \& Prod. Manag., 32(3), pp. 329-350. 
APPENDIX A. DETAILS OF CASES

\begin{tabular}{|c|c|c|c|c|c|c|c|c|c|}
\hline 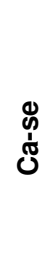 & 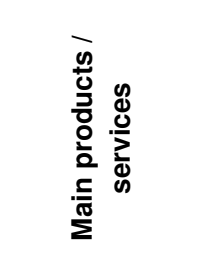 & 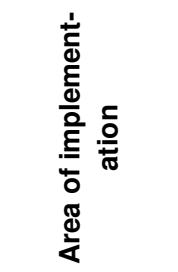 & 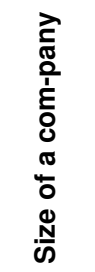 & 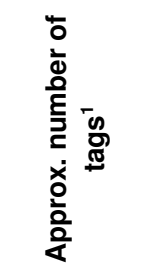 & 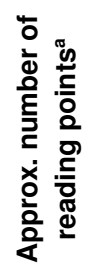 & 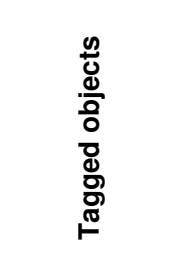 & $\begin{array}{l}\frac{0}{\circ} \\
\frac{0}{1} \\
\frac{1}{0} \\
\frac{0}{0} \\
\frac{0}{0} \\
\frac{1}{\Phi} \\
\frac{0}{0}\end{array}$ & 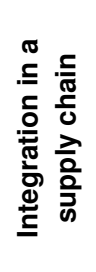 & $\begin{array}{l}\frac{0}{0} \\
\frac{0}{0} \\
\frac{0}{0} \\
\frac{1}{5} \\
\text { के }\end{array}$ \\
\hline A & $\begin{array}{l}\text { Transportation } \\
\text { of fuel }\end{array}$ & $\begin{array}{l}\text { Rail } \\
\text { logistics }\end{array}$ & Large & 12,000 & 200 & Rail cars & Closed & Yes & $\begin{array}{l}\text { UHF } \\
\text { EPC }\end{array}$ \\
\hline B & $\begin{array}{l}\text { Freight } \\
\text { transport by } \\
\text { road and } \\
\text { warehousing } \\
\text { of fresh goods }\end{array}$ & $\begin{array}{l}\text { Monitoring } \\
\text { and tracking } \\
\text { of forklifts } \\
\text { and } \\
\text { temperature }\end{array}$ & Large & 30 & 100 & $\begin{array}{l}\text { Forklift } \\
\text { trucks }\end{array}$ & Closed & No & $\begin{array}{l}\text { UWB } \\
\text { RTL } \\
\text { S }\end{array}$ \\
\hline C & Paper & $\begin{array}{l}\text { Monitoring } \\
\text { of trucks in } \\
\text { recycling } \\
\text { plant }\end{array}$ & Large & 30 & 4 & Trucks & Closed & No & $\begin{array}{l}\text { UHF } \\
\text { EPC }\end{array}$ \\
\hline D & $\begin{array}{l}\text { Bulk } \\
\text { chemicals for } \\
\text { construction } \\
\text { industry }\end{array}$ & $\begin{array}{l}\text { Warehousin } \\
\text { g of finished } \\
\text { goods }\end{array}$ & Large & $\begin{array}{l}150,000 \\
\text { per year }\end{array}$ & 15 & $\begin{array}{l}\text { Pallets of } \\
\text { finished } \\
\text { goods }\end{array}$ & Open & $\begin{array}{l}\text { Parti } \\
\mathrm{al}^{2}\end{array}$ & $\begin{array}{l}\text { UHF } \\
\text { EPC }\end{array}$ \\
\hline E & $\begin{array}{l}\text { Freight } \\
\text { transport by } \\
\text { road }\end{array}$ & $\begin{array}{l}\text { Tracking } \\
\text { moveable } \\
\text { assets }\end{array}$ & Large & 20,000 & 20 & $\begin{array}{l}\text { Trucks' } \\
\text { equipment }\end{array}$ & Closed & $\begin{array}{l}\text { No, } \\
\text { but } \\
\text { ready }\end{array}$ & $\begin{array}{l}\text { UHF } \\
\text { EPC }\end{array}$ \\
\hline $\mathrm{F}$ & $\begin{array}{l}\text { Bulk } \\
\text { chemicals for } \\
\text { agriculture }\end{array}$ & $\begin{array}{l}\text { Storage of } \\
\text { pallets of } \\
\text { finished } \\
\text { goods }\end{array}$ & Large & $\begin{array}{l}1,000,000 \\
\text { per year }\end{array}$ & 100 & $\begin{array}{l}\text { Pallets/ bags } \\
\text { of goods } \\
\text { Forklift } \\
\text { trucks }\end{array}$ & $\begin{array}{l}\text { Open }^{3} \\
\text { Closed }^{4}\end{array}$ & $\begin{array}{l}\text { No, } \\
\text { but } \\
\text { ready }\end{array}$ & $\begin{array}{l}\text { UHF } \\
\text { EPC } \\
\text { UWB } \\
\text { RTL } \\
S^{4}\end{array}$ \\
\hline G & $\begin{array}{l}\text { Rubber } \\
\text { products }\end{array}$ & $\begin{array}{l}\text { Quality and } \\
\text { returns of } \\
\text { sold goods }\end{array}$ & Large & $\begin{array}{l}500,000 \\
\text { per year }\end{array}$ & 10 & $\begin{array}{l}\text { Item level } \\
\text { finished } \\
\text { goods }\end{array}$ & Open & $\begin{array}{l}\text { No, } \\
\text { but } \\
\text { ready }\end{array}$ & $\begin{array}{l}\text { UHF } \\
\text { EPC }\end{array}$ \\
\hline $\mathrm{H}$ & $\begin{array}{l}\text { Freight } \\
\text { transport by } \\
\text { road; } \\
\text { Warehousing }\end{array}$ & $\begin{array}{l}\text { Warehouse } \\
\text { of goods of } \\
\text { customers }\end{array}$ & Large & $\begin{array}{l}1,000,000 \\
\text { per year }\end{array}$ & 100 & $\begin{array}{l}\text { Pallets of } \\
\text { goods } \\
\text { Forklift } \\
\text { trucks }\end{array}$ & $\begin{array}{l}\text { Open }^{c} \\
\text { Closed }^{d}\end{array}$ & $\begin{array}{l}\text { No, } \\
\text { but } \\
\text { ready }\end{array}$ & $\begin{array}{l}\text { UHF } \\
\text { EPC }\end{array}$ \\
\hline I & $\begin{array}{l}\text { Freight } \\
\text { transport by } \\
\text { road of fresh } \\
\text { goods }\end{array}$ & $\begin{array}{l}\text { Temperatur } \\
\text { e monitoring }\end{array}$ & Large & 100,000 & 100 & $\begin{array}{l}\text { RTIs } \\
\text { Trucks }\end{array}$ & Closed & $\begin{array}{l}\text { No, } \\
\text { but } \\
\text { ready }\end{array}$ & $\begin{array}{l}\text { UHF } \\
\text { EPC }\end{array}$ \\
\hline J & $\begin{array}{l}\text { Transhipment } \\
\text { services of } \\
\text { bulk goods }\end{array}$ & $\begin{array}{l}\text { Monitoring } \\
\text { of trucks in } \\
\text { yard and } \\
\text { facility }\end{array}$ & Large & 100 & 20 & Trucks & Closed & No & $\begin{array}{l}\text { UHF } \\
\text { EPC }\end{array}$ \\
\hline K & $\begin{array}{l}\text { Gaskets for } \\
\text { automotive }\end{array}$ & $\begin{array}{l}\text { Work in } \\
\text { progress } \\
\text { monitoring }\end{array}$ & Large & 500 & 20 & $\begin{array}{l}\text { Kanban } \\
\text { cards }\end{array}$ & Closed & No & $\begin{array}{l}\text { UHF } \\
\text { EPC }\end{array}$ \\
\hline L & $\begin{array}{l}\text { Road and rail } \\
\text { transport of } \\
\text { liquids }\end{array}$ & $\begin{array}{l}\text { Rail } \\
\text { logistics }\end{array}$ & Large & 1,000 & 5 & Rail cars & Closed & Yes & $\begin{array}{l}\text { UHF } \\
\text { EPC }\end{array}$ \\
\hline M & $\begin{array}{l}\text { Assembly of } \\
\text { automotive } \\
\text { subassemblies } \\
\text { and parts }\end{array}$ & $\begin{array}{l}\text { Work in } \\
\text { progress } \\
\text { monitoring }\end{array}$ & Large & 100 & 10 & $\begin{array}{l}\text { Kanban } \\
\text { cards }\end{array}$ & Closed & No & $\begin{array}{l}\text { UHF } \\
\text { EPC }\end{array}$ \\
\hline
\end{tabular}

\footnotetext{
${ }^{1}$ considered in roll-out

${ }^{2}$ via barcode on labels, but ready for full integration

${ }^{3}$ pallets

${ }^{4}$ forklifts

${ }^{5}$ returnable transport item
} 